\title{
DYNAMICS OF CALORIE INTAKE IN RURAL BIHAR
}

Avanindra Nath Thakur*

\begin{abstract}
Based on the sample survey data of nearly 466 households collected from five villages of Katihar district located in North Eastern Bihar, the paper tries to identify some of the important factors responsible for change in calorie consumption of the population living at the margin. In a way, it also tries to establish the relationship between direct access to foodgrains from a variety of sources such as access to ownership of land, wages in kind, access to leased-in land, ownership of livestock, etc., with calorie intake of the rural population in the survey region. In doing so, it also, in a very brief manner, focuses on comparative role of other factors such as money and income in this regard. Further, there is also an attempt to highlight the variations in average calorie intake as well as chronic poverty across different occupational categories in the survey region and identify a set of factors responsible for such variations.
\end{abstract}

\section{Introduction}

Consumption pattern of the rural mass has hardly garnered consensus among economists and has been the focus of serious debates for almost last four decades. The significance of the issue cannot be overlooked as it has been the key to the entire calculation of poverty and central to the formation of several targeted government policy initiatives. However, this paper neither intends to give any kind of poverty estimates of the survey region based on calorie intake, nor tries to relate food intake with real income of sample households. The central theme of this paper is rather to throw some light on the pattern of calorie consumption of sample households in the survey region and to identify some of the key factors responsible for the level of calorie intake at the margin. In other words this paper tries to identify a set of factors which are key determinants of calorie intake in the survey region. Further, in doing so it also tries to give some policy suggestions for augmenting the provision of such factors in order to raise the calorie intake of the rural population at the margin.

*Assistant Professor, Department of Economics, Dr. B R Ambedkar College, University of Delhi, Email-avanindra.cesp@gmail.com

Journal of Rural Development, Vol. 36, No. 3, July-September : 2017 
The discussion in this paper is largely based on the information gathered from 466 randomly selected households in Katihar district (North Eastern Region) of Bihar for the financial year 2011-12. As is obvious, a majority of the households in the sample are primarily rural labour who sold their labour at least for a day during the preceding agricultural year in local area or in any other place. It has been a cumbersome task to identify any households within a certain category based on their work pattern (such as agricultural labour, nonagricultural labour, self-employed in agriculture, etc.), as there has been immense crisscross in their works. For instance, within a single household, there was hardly any similarity of work among its members- one person might work as self-employed in agriculture and other as casual labour, etc. Besides, one person in any household might work as agricultural labour during a peak agricultural season and thereafter move to non-agricultural sector during the slack season even within an agricultural year (in this paper the reference year is 2011-12). Nevertheless, an attempt has been made in this paper to categorise the households in various groups based on income criterion. Further, in order to disentangle the impact of access to agricultural land, households characterised as self-employed in agriculture are further divided on the basis of quantity of land they owned at the time of survey. This was done primarily to measure the impact of land ownership on consumption behaviour of any person in the surveyed households.

\section{Overall Consumption Patterns of Bihar}

As per the recent NSS reports (68th round on calorie intake), average calorie intake per capita per day in rural Bihar was $2242 \mathrm{Kcal}$ which happened to be slightly higher than all India average (2223 Kcal) and significantly higher than some of the richer States (in terms of per capita income) such as Gujarat (2024 Kcal) and Tamil Nadu (2052 Kcal). However, some States such as Punjab (2483 Kcal) and Haryana (2441 Kcal) show much higher calorie consumption in rural areas than Bihar. According to same NSS report, in rural Bihar, 59.3 percent of total expenditure was spent on food and cereals in 2011-12 which has been one of the highest in India (more precisely second after Assam). Higher share of food expenditure is rather not surprising as with such a low level of per capita income higher share of expenditure on necessities such as food and cereals becomes inevitable. However, the relevant question is that in spite of the low level of per capita income, rural Bihar managed to maintain its per capita calorie intake not only higher than that of the all India average but it is even higher than that for majority of States during the year 2011-12. This type of consumption behaviour not strongly linked with per capita income, compels us to think about the other factors than income which plays an instrumental role in determining the calorie intake in rural areas. In this context, this paper through primary survey tries to locate some of the important factors which affect food consumption and calorie intake in rural areas. 


\section{Contextualising the Sample Households}

The sample was collected from five villages of Katihar district. Four villages, namely, Bharri, Baraya, Babhangoan, and Gopinagar are located within the Mahananda river embankment and the fifth village, Bhamraili, is situated outside this embankment. Villages within the embankment are subject to vagaries of flood while Bhamraili, which is outside it, is generally free from occurrence of flood and consequent destruction in production. Definitely farming conditions in Bhamraili is better than all the other four villages under survey. Nevertheless, land fertility is found to be better in villages within the embankment. This happens primarily due to soil upgradation by the flood water almost every year. In any case all the five villages under survey are characterised by high fertility and water abundance. Groundwater in the villages range between 10 and $20 \mathrm{ft}$. Thus, irrigation through bore well is widespread in the region. In other words, almost all the agricultural lands in these villages are found to be irrigated. Thus, the agrarian condition here is moderately satisfactory except for the fact that some fluctuations in the production on an annual basis are evident due to occurrence of seasonal floods. Nevertheless, land in these villages, particularly in regard to productivity, cost of production and cropping pattern can be treated homogeneously.

This region echoes the general condition prevailing in the rest of the country, especially in the context of the caste profile vis-a-vis the class structure of rural population. The class of rural population to a large extent coincides with the prevailing caste structure even at this stage of economic development. Even though the entire region in terms of population is dominated by the other backward caste (OBC) group, the land ownership is more concentrated in the hands of the people belonging to the general category. In the sample, majority of the households belong to the OBC group and form more than $67 \mathrm{per}$ cent of the total sample size (Table 1).

Table 1: Caste Representation in the Sample

\begin{tabular}{|cccc|}
\hline Caste & Frequency & Per cent & Cumulative \\
\hline Gen & 20 & 4.3 & 4.3 \\
OBC & 313 & 67.2 & 71.5 \\
SC & 54 & 11.6 & 83.0 \\
ST & 79 & 17.0 & 100.0 \\
Total & 466 & 100.0 & \\
\hline
\end{tabular}

As has been stated at the outset, the collection of sample is based on the categorisation of rural labour. Therefore, the actual size of various castes in the sample is not a proportionate representation of actual caste configuration of the villages under the survey. The rural labour category, as has been defined under the study, mainly belongs to the SC and ST category and therefore, their representation in the sample has been higher than their proportion in total population. Further, the castes grouped under general category are less represented under rural labour and therefore, their representation in the sample is lower than their actual proportion in total 
population. However, in case of $\mathrm{OBC}$ group the deviation of such kind is not significant as they constitute a major part of the total population and their categorisation remained similar to the overall categorisation in the villages.

Table 2: Caste-wise Details of Average Assets in Possession

\begin{tabular}{|c|c|c|c|c|c|c|}
\hline Caste & & Land & Ownership & Operational Holdings & Total Asset Value & Total Loan \\
\hline Gen & $\begin{array}{l}\text { Mean } \\
\mathrm{N}\end{array}$ & & $\begin{array}{r}1.6675 \\
20\end{array}$ & $\begin{array}{r}2.8315 \\
20\end{array}$ & $\begin{array}{r}5200.0000 \\
20\end{array}$ & $\begin{array}{r}12100.0000 \\
20\end{array}$ \\
\hline OBC & $\begin{array}{l}\text { Mean } \\
\mathrm{N}\end{array}$ & & $\begin{array}{r}.3829 \\
313\end{array}$ & $\begin{array}{r}.5167 \\
313\end{array}$ & $\begin{array}{r}6006.7093 \\
313\end{array}$ & $\begin{array}{r}12006.4103 \\
312\end{array}$ \\
\hline SC & $\begin{array}{l}\text { Mean } \\
\mathrm{N}\end{array}$ & & $\begin{array}{r}1769 \\
54\end{array}$ & $\begin{array}{r}.2448 \\
54\end{array}$ & $\begin{array}{r}3240.7407 \\
54\end{array}$ & $\begin{array}{r}3572.2222 \\
54\end{array}$ \\
\hline ST & $\begin{array}{l}\text { Mean } \\
\mathrm{N}\end{array}$ & & $\begin{array}{r}.4028 \\
79\end{array}$ & $\begin{array}{r}.6122 \\
79\end{array}$ & $\begin{array}{r}3533.5443 \\
79\end{array}$ & $\begin{array}{r}3405.0633 \\
79\end{array}$ \\
\hline Total & $\begin{array}{l}\text { Mean } \\
\mathrm{N}\end{array}$ & & $\begin{array}{r}.4175 \\
466 \\
\end{array}$ & $\begin{array}{r}.6007 \\
466 \\
\end{array}$ & $\begin{array}{r}5232.2961 \\
466 \\
\end{array}$ & $\begin{array}{r}9569.6774 \\
465 \\
\end{array}$ \\
\hline
\end{tabular}

Note: $\mathrm{N}$ is the total number of households in corresponding categories.

Asset ownership pattern shown in Table 2 unambiguously reflects the inequality prevailing in various kinds of asset ownership with respect to caste categories in the region. The households belonging to general category possess significantly higher ownership holdings (around 1.67 acres per households on average) than the other caste groups ( 0.5 acre of land ownership per household). In terms of ownership holdings, the ST category households occupy the second position. The relatively higher average holdings of this group than both SC and OBC groups are mainly because of the implementation of land redistribution by the government agencies. However, this redistribution remained limited to a few habitations and a significant proportion of their population remained bereft of any benefit regarding the transfer of ownership rights. A majority of the $\mathrm{OBC}$ population was found to be either landless or having insignificant amount of land.
In general, landholding in the region, as expected, was found to be extremely skewed. Some households were possessing livestock as an additional means of livelihood. In any case, most of the respondents in the survey were either rural labour working in agriculture or related activities or marginal farmers. Thus, there were a few sources of livelihood in the region which used to play a key role in determining the livelihood condition of the households in the region. Therefore, calorie intake, being one of the most important aspects of well-being, is expected to be influenced by these sources of livelihood.

\section{The Model}

The following linear regression is run by taking calorie intake per person per day as dependent variable and the square root of agricultural land (in acres) per family member, gross labour days per person, total access to 
grain per person and value of animal asset per family member as independent variables. The regression is repeated by changing agricultural land with operational holdings in order to have a comparative analysis of ownership holdings and 'lease-in' lands in determining the level of per capita calorie consumption in rural areas.

In order to have the analysis based on food consumption, the total food consumption of various items were converted into kilo calorie $^{1}$ and then per capita per day consumption of calorie had been taken as the dependent variable. Model 1 (Table 3 ) is a regression analysis which tries to establish the relationship of per capita per day calorie intake with agricultural land, total working days per person, asset value per person and access to foodgrains per person. Here access to foodgrain per person includes all wages or part of the wage given in kind, the proceeds of the sale by any self-employed paid in kind and any kind of access to foodgrain over and above cash income. In other words, direct access to foodgrains by any source is taken separately as access to foodgrain and per person availability of such foodgrain is taken as one of the independent variables. Further, it is assumed that access to animal assets is also an important source of direct access to food. For instance, possession of cows ensures the availability of milk in the family and ownership of small animals as well as birds is also considered as access to direct food. It was observed that a significant proportion of labour households which owned such kind of animal or bird assets used to have higher content of food of such possession.

Table 3: Regression Result for Calorie Consumption Per Capita Per Day

\begin{tabular}{|c|c|c|c|c|c|c|}
\hline & Model 1 & & & Model 2 & & \\
\hline & Coefficient & t static & $p>[t]$ & Coefficient & t static & $p>[t]$ \\
\hline Constant & $1902.7 *$ & 36.78 & 0.005 & 1783.78* & 26.23 & 0 \\
\hline $\begin{array}{l}\text { (Agricultural } \\
\text { land } P C)^{\wedge} 0.5\end{array}$ & $535.15(0.17)^{*}$ & 2.84 & 0 & & & \\
\hline $\begin{array}{l}\text { Total labour } \\
\text { days PC }\end{array}$ & $1.46(0.08)^{* *}$ & 2 & 0.046 & $1.68(0.1)^{* *}$ & 2.26 & 0.024 \\
\hline $\begin{array}{l}\text { Food access } \\
\text { PC }\end{array}$ & $1(0.1)^{* *}$ & 2.45 & 0.015 & $1(0.1)^{* *}$ & 2.45 & 0.015 \\
\hline $\begin{array}{l}\text { Asset value } \\
\text { PC }\end{array}$ & $0.07(0.21) *$ & 3.16 & 0.002 & $0.07(0.21)^{*}$ & 3.45 & 0.001 \\
\hline $\begin{array}{l}\text { (Operational } \\
\text { holdings }\end{array}$ & & & & & & \\
\hline$P C)^{\wedge} 0.5$ & & & & $284.8(0.18)^{*}$ & 3.25 & 0.001 \\
\hline $\mathrm{R}$ square & 0.11 & & & 0.11 & & \\
\hline Prob $>$ F & $0 *$ & & & 0* & & \\
\hline Observations & 447 & & & 447 & & \\
\hline
\end{tabular}

Note: Values in the parentheses are standardised coefficient; *1 per cent, **5 per cent and ***10 per cent level of significance. All the independent variables are also expressed as per person.

Journal of Rural Development, Vol. 36, No. 3, July-September : 2017 
The result of the regression is extremely interesting.The coefficients of square root of ownership of agricultural land, gross labour days per person, per person value of the animal asset, per person access to the foodgrains and constant are 535.15, 1.46, 1, 0.07 and 1902.69, respectively and all these coefficients are statistically significant at different levels. It seems plausible to discuss the results on the basis of different factors responsible for consumption behaviour.

\section{Ownership of Land}

First and foremost factor which affects the level of consumption or calorie intake in the survey region is ownership of land. This happens from three dimensions: first, cultivation in own land gives rise to income level of households and with higher income people at the margin suddenly get higher purchasing power and hence food consumption with all probability tends to rise and second, cultivation of crops particularly foodgrain crops make a farmer in possession of increased command over foodgrains and hence end with possibility of higher calorie intake. In other words, access to cultivable land directly gives rise to access to foodgrains, particularly for consumption purposes. Third, ownership of land would in turn lead to possession of crop remains which are largely used as fodder for livestock. Therefore, owning (or maintaining) livestock becomes easier with ownership of land. Since ownership of livestock in itself is a possible factor affecting calorie intake (discussed separately in later part of this paper) indirectly, ownership of land is expected to affect calorie intake over and above its direct role.

In regard to the nature of land ownership and its effect on calorie consumption, it is important to discuss the reasons for inclusion of square root of ownership instead of merely the ownership level in the model. The inclusion of square root of agricultural land in the model shows that with increase in the amount of ownership of such lands, calorie intake increases, but at a decreasing rate. This seems obvious as a small size of land ownership is sufficient to convert a family from calorie deficient to calorie sufficient. Beyond that amount of land ownership, the direct impact of land ownership on calorie intake gets lower in degree. In other words, if a family owns one acre of land and does not have any other source which affects calorie consumption such as livestock holding, wage income, no other direct access of foodgrain from any sources, still his / her value of total consumption based on our model would be higher than $2400 \mathrm{Kcal}$ per day. This happens as the coefficient of land ownership in acres in the model is 535 , which says that one additional unit of land ownership would raise calorie consumption by 535 units. Thus, a movement from one acre to two acres will not have same impact on the calorie intake as compared to the movement from landless to one acre of land. The change in the calorie intake in the latter case would be certainly higher than the former situation. Nevertheless, the impact of ownership of land remained positive on calorie intake in the 
entire range of ownership taken into consideration in the sample.

\section{Number of Employment Days}

The other important factor affecting the average calorie intake in the region has been the number of working days during a year. Effectively,the main source of income for majority of persons in the survey villages is wage income. Therefore, it is important to assess the role of availability of working days on calorie intake of an individual worker. In other words, availability of wage employment in the region on regular and casual basis within and outside the village is expected to have significant bearing on the consumption pattern of labour households. Over and above casual/regular work provided in both farm and non-farm sectors in the survey region also included labour days of migrant labour worked in his/her place of migration during the agricultural year 2011-12. Migration in this region is mainly seasonal in nature and labourers migrate for two to three months during agricultural slack season (which happened to be from August to October). Therefore, total number of working days under migration remains limited. Further, almost all of them got engaged in informal sector in their place of migration, thus the daily wage they received did not significantly vary from that of their native place. Adjusting for their cost of living, travelling cost and other liabilities, net earnings from migration remained far from being significant. Thus, in the regression analysis it ceases to become an independent variable separately in determining calorie intake. Nevertheless, its importance in increasing working days and providing additional wage income can never be ignored.

Total number of employment days also included work done under Mahatma Gandhi National Rural Employment Guarantee Scheme (MGNREGS). This scheme though had significant impact on various tenets of local job market such as raising the floor wage rate, increasing the income of labour households, strengthening the bargaining power of rural labour in non-public sector, etc., nevertheless its impact on calorie intake remained far from being significant. This was primarily due to the fact that rampant corruption was witnessed during the survey particularly at implementation stage of the scheme. Average number of employment days provided under this scheme during the year 2011-12, as found in this survey, was not more than 20 , which happened to be far below the actual provision of 100 days per family per annum. Further, irregularities were also found in disbursing the wages to the labourers. In other words, in a family with five members, availability of working days under this scheme on an average was around 5 per member / person. Thus, individually this scheme ceases to become an independent variable in determining consumption level of rural labour at the margin. However, without any doubt, it contributed in calculating total employment days per person in the region which happened to be an independent variable with significant impact on calorie consumption.

The regression result shows that the coefficient is significant at 5 per cent level 
and the value of the coefficient is 1.46 . The magnitude of the coefficient for labour days per person reflects that though there is a positive relationship between work availability and calorie intake of labour households, the relationship is in fact weaker than what is generally understood. In other words, given other things, one additional day of employment on an average contributes $1.46 \mathrm{Kcal}$ worth of consumption for the sample households. Thus, in the absence of other factors such as land ownership, access to direct food, livestock ownership, a person has to work for more than 240 days in an agriculture year to achieve the consumption of $2400 \mathrm{Kcal}$ per day.

It was also evident in the survey that average days of work a labourer gets in the entire agricultural year happened to be less than 100. Adoption of labour-displacing technologies and creeping mechanisation has been responsible for decline in the demand of labour in agricultural operations. The survey region witnessed visible pace of mechanisation in agriculture, for instance use of tractors, weedicides and to a large extent increasing use of combine harvester had led to sharp decline in demand for labour in various agricultural operations in these villages. Since this survey was cross-sectional and taken at a particular time period, it's difficult to capture any such decline over a long period of time. However, there are sufficient field-based papers which show the evidence of continuous fall in labour absorption in agriculture in different places of the country. For instance, J ha and Thakur (2016) found that the average days of employment in agricultural sector remained less than 100 days during the entire agricultural year in some surveyed villages in Bihar. This figure shows a clear decline when compared to the figure of around 120 days per annum reported during the previous two surveys, in 2003 and in mid1980s. Similarly, a field-based study in three villages in Andhra Pradesh by Ramachandran and Rawal (2010) shows that in the farm sector, the average number of days of employment available to male and female workers was around 101 and 84 days, respectively. The extent of secular decline in the absorption capacity of agriculture is also evident from the fact that the average number of working days for an agricultural labour family in a village situated in coastal Andhra Pradesh in 1976 was around 247 days (Sundarayya, 1976), while only 195 days as recently reported by Ramachandran and Rawal (2010). Similar evidence of decline in agricultural employment is reported for villages in Eastern Uttar Pradesh (Srivastava, 1998).

Therefore, there is no reason to believe that the survey region is free from such declining trend of labour demand in the farming process. Further, low level of average manual working days evident in the survey also confirms the same. In this scenario it is easily discernable that casual labourers who constitute majority of the workforce in survey region find themselves in an extremely helpless situation in regard to having access to adequate calorie intake. 
Nevertheless, regular employment in this regard assumed greater significance. Unfortunately, in agriculture there were only a small number of persons who had been employed on regular basis as found in the survey. Rapid fall in regular employment in agriculture has been one of the most perceivable characteristics not only in the survey region but throughout the country. Several field studies during the last four decades or so, have reported such a trend, for instance, Da Corta and Venkateshwarlu (1998) for Andhra Pradesh, Lerche and Srivastava (1998) for Uttar Pradesh, Jha (1997) for Bihar and many other studies confirmed significant decline in the incidence of regular employment in rural areas. A study of Purnia district, adjacent to Katihar in Bihar also confirms such trend over the last three decades. Also, repeated field surveys done in two villages (Barahari and Majra) of Purnia district in Bihar from 1987 to early 2012 point to an acceleration in the decline of regular wage arrangements ( ha and Thakur, 2016). In this survey, the proportion of regular labour/ attached labour in the agricultural sector was found to be as low as less than 2 percent of total sample size. Thus, a trend of declining availability of working days in agricultural operations (both on the casual and regular basis) along with relatively weaker marginal effect of employment days on calorie intake in the survey region, makes the condition of households solely dependent on wage earnings susceptible. In other words, assetless/ propertyless workers are extremely vulnerable in regard to having access to adequate calorie intake in rural areas.

\section{Direct Access to Foodgrain}

There were several processes evident in the survey region through which a person had direct access to foodgrain. Firstly, some attached labour instead of taking food in employers' house, preferred to take away some grain and this was generally fixed at around $50 \mathrm{~kg}$ rice a month. This kind of arrangement was seemed preferable for both the parties and was found in almost all the cases of 'attached labour' in the survey region. Under this arrangement, the employer can avoid cooking food for their attached labourers. This is generally preferable for the employer as cooking in the absence of adequate domestic help undoubtedly becomes a cumbersome task. Further, giving cooked food involves pulses and vegetables in addition to rice which the employer can avoid by giving only raw rice that too generally harvested from his / her own farm. For the labourer it is preferable mainly on the following accounts: first, $50 \mathrm{~kg}$ rice is significantly higher than the amount which is consumed by any labourer in a month. Second, these attached labourers under this arrangement used to have freedom to take food of their choice with their family members.Third, in most of the cases labourers preferred a fixed share of produce as their wage in the harvesting processes of foodgrain crops. The share of this kind varied from onetenth to one-twelfth of the total produce. Fourth, almost all kinds of food processing 
activities involved certain share of grain as payment in lieu of processing. For instance, the charges for preparation of rice from paddy, preparation of flour from wheat, preparing oil from mustard seeds were taken in kind in the form of a particular share of respective raw food items. Fifth, most of the shopkeepers used to take a particular amount of foodgrain as payment against the purchase of non-food items by other households. Finally, food access through various government schemes such as Public Distribution System (PDS), Integrated Child Development Services (ICDS) and Antyodaya are also included in this category. Here, access to foodrain through PDS was widespread as most of the respondents were entitled to get foodgrain on monthly basis under this scheme. However, the unit of foodgrain disbursement is 'family', per capita availability of food under this category becomes generally very small. Besides, a small number of extremely poor households in the sample got access to Antyodaya scheme in which foodgrain is made available at negligible prices. Again the unit of disbursement under this scheme is 'family', thus per capita availability of foodgrain under the same head becomes relatively small. As far as ICDS is concerned, it is made available to either pregnant women or children below the age of 6 years. Under this scheme, as evident in the survey region, beneficiaries used to get proteins, vitamins and iron rich food items for which calorie component remained lower. Nevertheless, any disbursement of any kind of foodgrain in this scheme is included as access to foodgrain in the model.
Therefore, access to foodgrains from all those sources combined and averaged over the family members are taken under the head of access to food per capita in the regression model. In the regression exercise it is evident that access to food per person has been one of the key factors in determining the calorie intake of any concerned person. The coefficient of food access per person has come out to be nearly 1 and it is significant at 5 percent level. By looking at standardised coefficients of gross labour days per person (0.08) and food per person food access (0.1), it is easily discernable that the latter is relatively more important in determining calorie intake as compared to the former. Further, gross labour days in certain proportion also includes wage in kind, which in turn has been significantly influential in determining the overall level calorie consumption. Therefore, intuitively it is clear that the actual impact of total labour days per person has been much lower as compared to the direct food access per person. More surprisingly, total income per person did not have a significant impact on the calorie intake ${ }^{2}$ which shows that at the lower rung of the economic ladder it is the direct access to food which plays an instrumental role in determining the overall consumption of foodgrain. Based on the above model, it is indeed interesting to compare wage income and wage in kind in regards to their impact on calorie intake in survey region. The average wage rate for a person during the financial year 2011-12 was found to be ₹ 125 a day. During the same year the wage rate was 
equivalent to nearly $8 \mathrm{~kg}$ of rice in that particular region. Thus, average wage in terms of rice was nearly $6-8 \mathrm{~kg}$ a day. According to the model, one additional labour day of employment on an average could raise 0.08 Kcal intake.Therefore, in terms of impact on calorie intake in kind wage is nearly 6-8 times more effective than equivalent amount of total income from wage. This clearly reflects the greater significance of access to foodgrain as compared to cash in order to have incremental impact on calorie consumption particularly for the people at the margin. Higher standardised coefficient of wage in kind than that of total labour days also confirms the same.

\section{Livestock Ownership}

Generally speaking, food intake in villages in general depends heavily on variety of animal products such as cow milk, goat meat, chicken, pig meat, etc. The impact of livestock on consumption patterns of rural households again works in two ways: first, being one of the important sources of livelihood it enhances the purchasing power of the concerned households; second, being a good source of calorie and protein, command over these animals in general automatically gives access to higher quality food with rich calorie value. In survey process it was evident that a substantial number of households confirmed their food habit influenced by their occupation and consequently availability of food items in their command. For instance, rice and wheat intake was found to be relatively higher for farmers, milk intake was generally higher for those households having either ownership of cow or possessing cow on sharing basis, fishermen's food intake was relatively biased towards fish and so on. Thus, in this context, the impact of livestock ownership was expected to have positive impact on calorie intake. However, the actual difficulty in order to measure the impact of livestock ownership on calorie consumption has been quantification of the former. Here, in the regression model, this difficulty was tried to be addressed by taking the market value of animal possessed as a proxy to their calorie equivalence.

The relationship in this respect is quite apparent in the regression exercise. The magnitude of coefficient for value of livestock per family member comes out to be 0.07 . In terms of relative importance of different factors discussed in the model, ownership of livestock has been the most important one affecting calorie intake of an individual within the sample in the survey region. This is confirmed by the fact that standardised coefficient of the variable has been 0.21 . In other words, measured in terms of standard deviation nearly 21 per cent change in the value of calorie intake is due to the change in the value of livestock ownership in the region. Thus, direct access to animal products such as milk, meat, etc., happened to be the most important factor responsible for the level of calorie consumption in the survey region.

Therefore, the impact on total calorie intake can be assessed in two ways: in all, it 
is clear that jointly all the sources of direct food access are generally responsible for more than 50 per cent of the change in calorie intake while change in gross labour days per person which is generally direct money income is responsible for less than 10 percent of the change in the calorie intake for any person given other things are constant.

\section{Operational Holdings}

In view of the given scenario, one is tempted to enquire if the level of calorie intake varies according to the nature of holdings. This is quite clear from the regression results of model 2 (Table 3). Here agricultural land ownership per family member is replaced by operational holdings per family member. Operational holdings also allow leased-in land; in other words, this is nothing but the total land under possession per family member. In the second model, as expected, the coefficient of square root of operational holdings per family member becomes relatively lower (284.80) as compared to that for agricultural land ownership (Table 3 and model 2). In other words, the coefficient of square root of operational holdings is nearly half of the coefficient of square root of agricultural land ownership. Nevertheless, the impact of operational holdings on the calorie consumption per person per day is significant at one per cent level. Arguably, access to 'lease-in land' in turn provides direct access to foodgrain as a particular share of total produce is possessed by the tenants. Thus, one may argue that the relationship between operational holdings and calorie intake should be the positive one. However, the pertinent question that needs to be addressed here is that what makes ownership holdings and operational holdings so different in terms of their impact on calorie intake.

In order to give answer to such questions it is an imperative to have a deeper look at the pattern of tenancy in the survey region. Primarily two kinds of tenancy contracts were prevalent in the survey region: one, sharecropping, in which some part the expenditure as well as final harvested farm produce are shared by the tenants and two, fixed rent contracts in which rent of the land is fixed either in cash or in terms of some predetermined quantity of farm produce. Second type of contract was prevalent mainly in maize cultivation while shared contracts were dominant in traditional crops such as paddy and wheat. Evidently, there has been a shift in tenancy pattern in this region from sharecropping to fixed rent contracts. This shift has had an important bearing on access to foodgrain particularly for tenants. Firstly, landlords were generally found reluctant to give their land to tenants for paddy or wheat cultivation as fixed rent contracts for maize was more lucrative for them. Moreover, due to uneven sharing of cost of cultivation for paddy and wheat, even tenants in most of the cases preferred fixed rent contracts for maize rather than other traditional foodgrains. This trend in general reduced, in a very significant manner, the availability of 'leased land' for paddy or wheat cultivation. Since maize is rarely used as staple food in the region, the tenants in 
this case most often possessed cash instead of foodgrain through the rent contracts. As is evident in foregoing exercise, direct access to foodgrain remained relatively more important factor affecting calorie intake, the impact of inclusion of leased-in land is bound to weaken the relationship between land and calorie intake in the region. Secondly, in case of shared produce contracts, it was found that the terms of contracts were heavily weighted against the tenants as they used to share higher proportion of total cost of cultivation (only irrigation, seed and fertiliser costs were shared by landlords and costs associated with ploughing, weeding, harvesting, etc., were totally carried out by the tenants). Moreover, it was also evident that due to inadequacy in regard to availability of cash in the hands of tenants, in majority of the cases they had to rely on their landlords for timely completion of various cultivation activities. The landlords used to take back this additional expenditure in terms of possession of higher than the agreed upon share of total produce. This usually ended up in lower than expected share of total foodgrain in the possession of tenants. And, thus, it also contributed to place 'leased-in' land in relatively disadvantaged position as compared to ownership holdings.

Nevertheless, given the limitation of availability of wage employment in the region and inadequacy in regard to non-agricultural employment, the role of 'leased-in' land in affecting the calorie intake either directly through access to foodgrain or indirectly through the additional source income should not be underestimated. Moreover, livestock ownership is expected to have a positive relationship with operational holdings as it gives the tenants' access to half of the crop remains which is widely used as fodder, the impact of the latter on the calorie intake of any person would be much higher than the actual level reflected through the coefficient. Thus, access to land even in a broader sense i.e., including leased-in land has significant impact on calorie consumption in the region under the survey.

\section{Broad Household Types and Calorie Consumption}

As mentioned earlier, due to crisscrossing of economic activities both within a family and temporally for most of the labourers in the region, it was a cumbersome task to categorise households in various standard ${ }^{3}$ categories. Further, as explained in the regression analysis, the importance of land, access to foodgrain, etc., in determining the calorie intake has been immense. Therefore, it is desirable to categorise the households, to the extent feasible, on the basis of above-mentioned factors. Thus, all the households in the survey region were grouped into nine categories. The households primarily self-employed in agriculture are basically divided into five categories: 1)households without having ownership of land but cultivate leased-in land (f0), 2) households having less than 0.5 acre of land (f0.5), 3) households having ownership of land between 0.5 and 1 acre (f1), 4) households having ownership of land between 1 acre and 2 acres (f2), 5) 
households having ownership more than 2 labour $(\mathrm{Cl})$, regular worker in non-farm sector acres of land (f3). Other categories of (Reg) and finally self-employed in non-farm households included in the study are: attached sector (Senonagr). Following Table and Figure labour (At) which happened to be salaried/ show average per capita per day calorie intake regular employed in the farm sector, casual for each of the said categories of households.

Table 4: Distribution of Households and Average Calorie Intake for Different Categories of Households

\begin{tabular}{|lccc|}
\hline Broad Household Type & Frequency & Per cent & $\begin{array}{c}\text { Kilo Calorie Per } \\
\text { Person Per Day }\end{array}$ \\
\hline At & 9 & 1.93 & 2347.56 \\
Cl & 277 & 59.44 & 2020.88 \\
f0 & 39 & 8.37 & 2255.05 \\
f0.5 & 44 & 9.44 & 2325.53 \\
f1 & 27 & 5.79 & 2482.58 \\
f2 & 26 & 5.58 & 2373.99 \\
f3 & 6 & 1.29 & 2749.12 \\
Reg & 18 & 3.86 & 2492.75 \\
Senonagr & 20 & 4.29 & 2445.12 \\
Total & 466 & 100.00 & 2167.82 \\
\hline
\end{tabular}

Figure 1: Broad Households' Type and Average Calorie Consumption

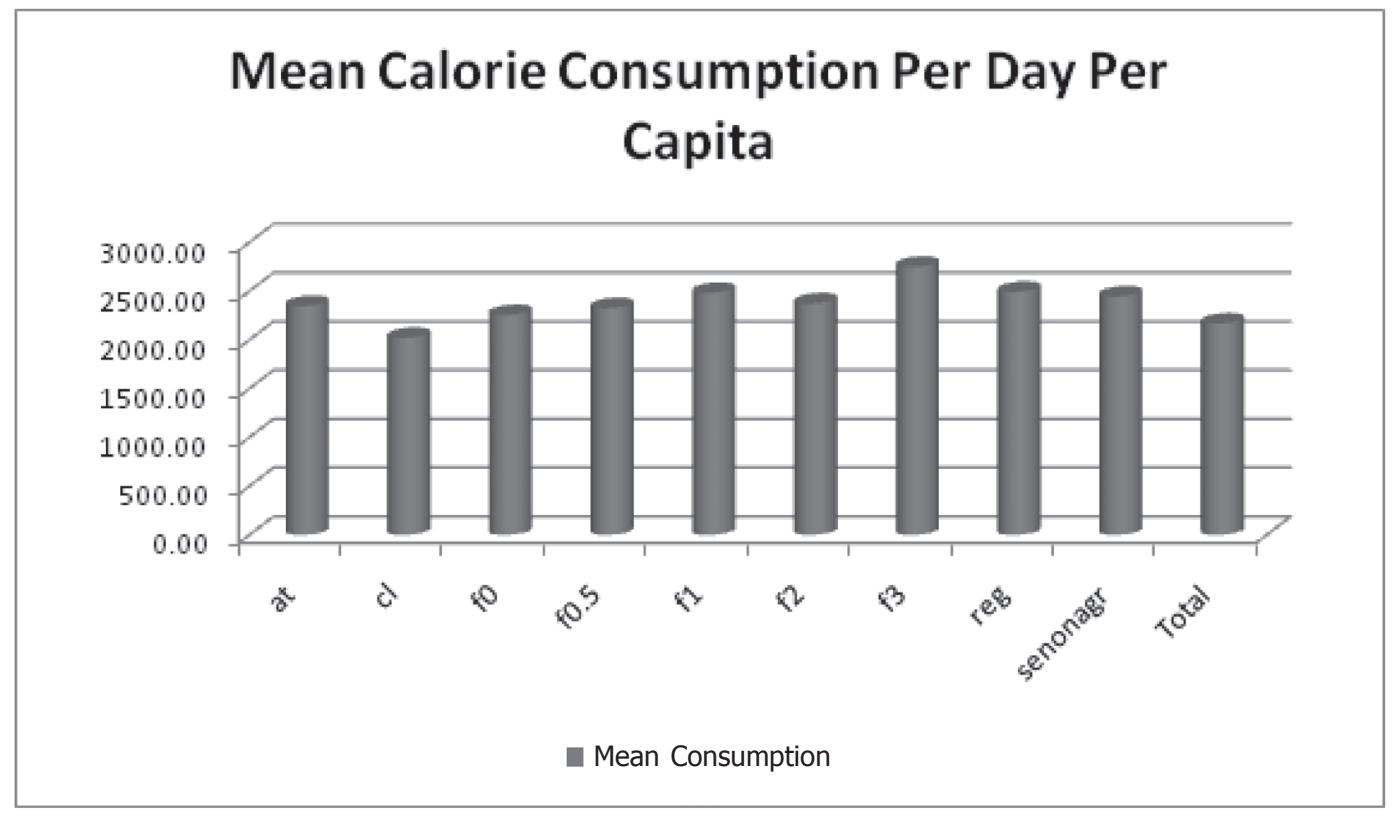

Journal of Rural Development, Vol. 36, No. 3, July-September : 2017 
Division of households based on aforementioned basis, to a large extent, provides an insight of various factors or conditions affecting average calorie intake of the concerned households in the survey region. A look at the calorie intake pattern among different categories of rural population also brings forth the impact of some other factors which are as follows: it becomes conspicuous that per day per capita calorie intake was the lowest for casual labour households. The reason for such inadequacies lies in the lack of access to land. Attached labour households are relatively better off in this regard, because they have access to land, generally leased-out to them by their employers. Besides, these labourers generally take their food at their employer's residence or take some rice instead of having direct food. In the latter case, the average amount of rice per month was found to be around $50 \mathrm{~kg}$. Their salaries on regular basis, though remained far from being adequate, have also been helpful in maintaining calorie level at levels which are at least higher than the landless casual labour households. Nonetheless, with relatively low average salaries a large proportion of these households were not able to consume the amount needed to have the minimum requirement of $2400 \mathrm{Kcal}$ per day. However, access to land and provision of food (as part of the salary) helped most of the households of this category in maintaining a relatively moderate level of consumption.

For those households which do not have ownership holdings but have some level of access to lands on lease, the average calorie intake is lower than that for attached labour but higher than the category of casual labour. The average amount of land available for this category (f0) is very low and is generally given on lease for a single crop season. Again, because of adverse profitability conditions due to consequence of high rate of prevailing rent, these tenants lack enough income to avail of the desired food intake. Further, generally maize is the crop of choice for cultivation, especially in the case of the fixed rent lands. The calorie intake is generally higher for those categories with higher land ownership. However, the families having ownership holdings between one to two acres of land prove to be exceptions. They show lower calorie intake than those families with slightly lower level of ownership holdings. A few observations might be made to unravel this element of surprise in calorie consumption. Firstly, till one acre of land ownership, most of the families are engaged in selling of their labour power. Such households prefer to get engaged in harvesting in order to have access to some more foodgrain as kind wage. It was frequently seen in these villages that some of the households with some level of land ownership preferred to work as agricultural labour only for harvesting of paddy and mustard. The families with some level of lands or more precisely between 0.5 to 1 acre of land were observed to opt quite frequently for harvesting of food crops in other's field and hence had additional access to foodgrain. However, the next group of households having ownership holdings more than one acre rarely 
sell their labour. Their only source of foodgrain is their own cultivation. It was also evident in the survey that with higher than one acre of land the ratio of hired labour to family labour becomes very high. Thus, with higher wage bill and lower level of land these households hardly find the entire farming exercise to be lucrative.

The families with higher than three acres of lands include some large farmers and their significantly higher level of calorie intake does not come as a surprise. With higher level of income and generally higher land ownership, average calorie intake of the regular income families also crosses the $2400 \mathrm{Kcal}$ norm without much hardship. For the families having self-employment in non-agriculture, income status in most of the circumstances is higher than some of the other groups. Besides, one of the major patterns of transaction within the self-employment activities is in kind. For instance, several shopkeepers prefer foodgrain as against hard cash for their sales. This increases their accessibility to food and important source of their food stock. They, being in most of the cases, monopolistic sellers, also remained successful in keeping the transaction prices for such foodgrains much lower than the market prices.

Thus, on the whole the occupational status as well as access to lands have significant impact on the level of consumption and hence calorie intake per capita. All the categories of households having access to land either through ownership or leased-in (e.g., At, f0, f1, f2, and f3) in general performed better in terms of average calorie intake. Further, some occupations such as regular/ salaried employment and self-employment in non-farm sector remained relatively better in this respect partly due to higher average income and partly due to indirect access to foodgrain particularly in case of self-employed in non-farm sector. On the whole, there is hardly any doubt that the most disadvantaged group happened to be the casual labourers in the survey region. Their wage earning was neither sufficient to fulfill the calorie need nor they had adequate access to foodgrains from other sources and thus remained primarily deprived of calorie sufficiency in general. The unfortunate part is that the share of casual labour in total households in the survey region has been significant. As shown in the Table, nearly 60 per cent of the total households in the sample came under this category. Thus, it is difficult to reject the hypothesis that nearly 60 per cent of the population in the survey region were subject to extreme calorie deficiency as the average calorie consumption of this group remained significantly lower (2021 Kcal per day) than the desired level of consumption (2400 Kcal per day).

Calorie deficiency among different households could also be highlighted by bifurcating each of the above groups on the basis of two categories: first, those who were successful in having access to at least 2400 Kcal per day per person and second, all other households. 
Table 5: Proportion of Households Having Access to 2400 Kcal Per Day Per Person Within Each Group

\begin{tabular}{|c|c|c|c|c|}
\hline \multirow{2}{*}{$\begin{array}{c}\text { Household } \\
\text { No }\end{array}$} & \multirow{2}{*}{$\begin{array}{l}\text { Type } \\
\text { Yes }\end{array}$} & \multicolumn{2}{|c|}{$\begin{array}{c}\text { Direct Poverty }(<2400 \\
\text { Kcal / day })\end{array}$} & \multirow[t]{2}{*}{ Total } \\
\hline & & & & \\
\hline \multirow[t]{2}{*}{ at } & Count & 4 & 5 & 9 \\
\hline & $\%$ within 'at' & $(44.4)$ & $(55.6)$ & $(100.0)$ \\
\hline \multirow[t]{2}{*}{$\mathrm{cl}$} & Count & 62 & 215 & 277 \\
\hline & \% within 'cl' & $(22.4)$ & (77.6) & $(100.0)$ \\
\hline \multirow[t]{2}{*}{ fo } & Count & 16 & 23 & 39 \\
\hline & $\%$ within 'fO' & $(41.0)$ & $(59.0)$ & $(100.0)$ \\
\hline \multirow[t]{2}{*}{ f0.5 } & Count & 17 & 27 & 44 \\
\hline & $\%$ within 'f0.5' & (38.6) & $(61.4)$ & $(100.0)$ \\
\hline \multirow[t]{2}{*}{ f1 } & Count & 12 & 15 & 27 \\
\hline & $\%$ within 'f1' & $(44.4)$ & $(55.6)$ & $(100.0)$ \\
\hline \multirow[t]{2}{*}{ f2 } & Count & 11 & 15 & 26 \\
\hline & $\%$ within 'f2' & $(42.3)$ & $(57.7)$ & $(100.0)$ \\
\hline \multirow[t]{2}{*}{ f3 } & Count & 3 & 3 & 6 \\
\hline & $\%$ within 'f3' & $(50.0)$ & $(50.0)$ & $(100.0)$ \\
\hline \multirow[t]{2}{*}{ reg } & Count & 9 & 9 & 18 \\
\hline & $\%$ within 'reg' & $(50.0)$ & $(50.0)$ & $(100.0)$ \\
\hline \multirow[t]{2}{*}{ senonagr } & Count & 10 & 10 & 20 \\
\hline & $\%$ within 'senonagr' & $(50.0)$ & $(50.0)$ & $(100.0)$ \\
\hline \multirow[t]{2}{*}{ Total } & Count & 144 & 322 & 466 \\
\hline & $\%$ within all households & $(30.9)$ & $(69.1)$ & $(100.0)$ \\
\hline
\end{tabular}

Note: Figures in parentheses indicate percentages.

Figure 2: Proportion of Households Having Access to 2400 Kcal Per Day Per Person Within Each Group

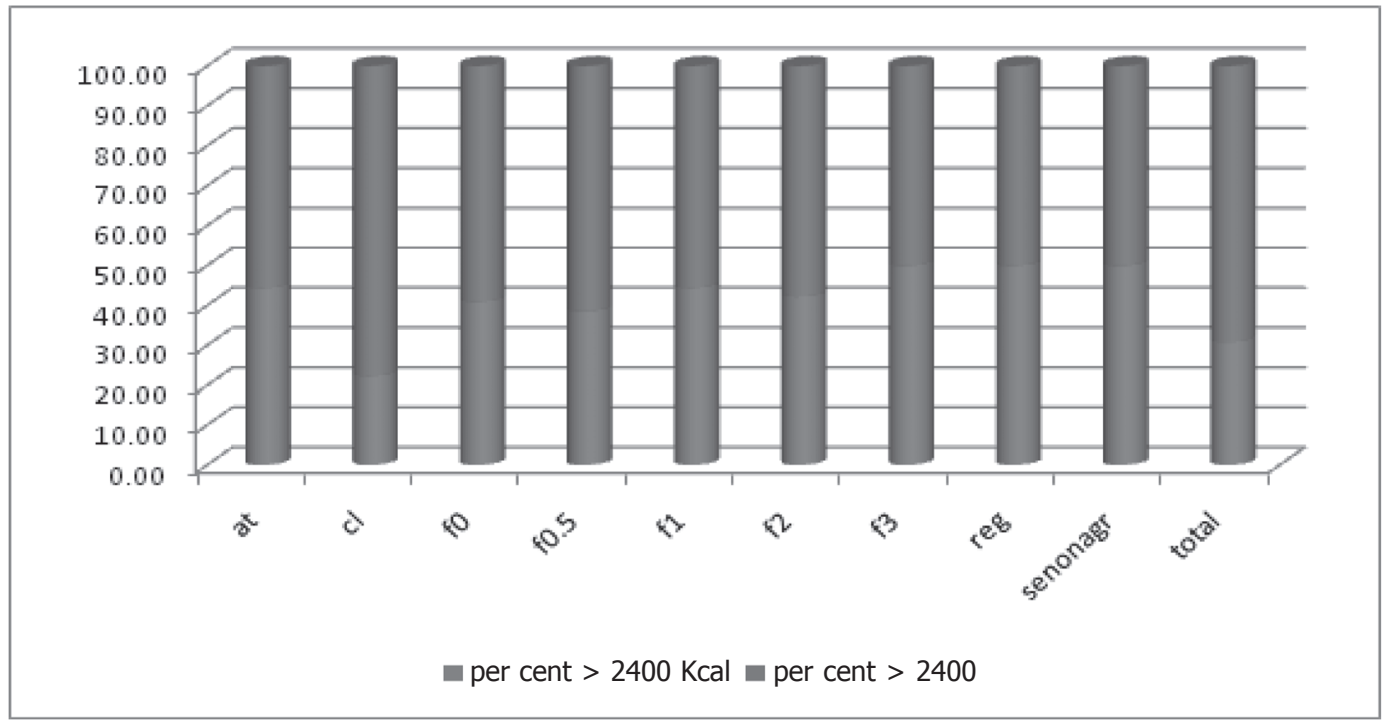

Journal of Rural Development, Vol. 36, No. 3, July-September : 2017 
If we take direct poverty within different categories of households into account the picture becomes clearer. Nearly 70 per cent of the sample households did not have access to $2400 \mathrm{Kcal}$ per day per person during the survey period. In other words, direct poverty in the region was found to be much higher than the indirect official estimates given by the Planning Commission. Secondly, this deprivation in calories was alarming for those households who were at the lower end in terms of access to land. More precisely, casual labourers were the real sufferers in this regard as more than 77 per cent of them were unable to access $2400 \mathrm{Kcal}$ per day during the survey period. However, households with relatively higher land ownership possessed lowest proportion of calorie deficient persons in the sample.

\section{Concluding Remarks}

Based on this analysis it can be concluded that the direct access to food whether by owning or leasing-in agricultural land or by other sources such as wage or income in kind, has been more influential than money income. This happens because a significant proportion of the population at the margin is perennially suffering from cash deficiency. So, with money income at their disposal they use their income in some other means rather on purchasing food items. Often the money is used to repay the loans taken from the local moneylenders at a very high rate of interest. Further, purchase of basic commodities of daily use from the market hardly leaves the masses with an extra amount to spend on consumption. One of the major expenditures which was found in families of most of the rural labour has been the expenditure on medical purposes. In the absence of proper and adequate provisions of government healthcare facilities, the villages have witnessed the mushrooming of local 'quacks'. These 'quacks' do not possess proper medical training and knowledge. The villagers are too illiterate to identify the frauds and too poor to avail of the proper medical facilities. As a consequence, they opt for those 'quacks' for their treatment and incur more expenses, often without access to proper healthcare facilities. It is for these reasons that more emphasis and importance shall be given to grain provisions under the public distribution system (PDS). Greater care shall be given to raise the level of calorie intake for the rural population at the margin rather than providing them with same worth of cash under the cash transfer scheme. The transfer of money intended to be used for calorie intake does not ensure the actual intake of calorie. This can be ensured only through direct access to foodgrains. The income criterion of poverty line and the support of PDS only to those below that line defeat the purpose of the support in this regard. Therefore, to counter the incidence of poverty in rural areas the need of the hour is universalisation of PDS and provisions of foodgrain directly to all the needy households without having any eligibility criterion and not of cash transfer. 


\section{Notes}

1. The conversion is based on the calorie values of various food items given by the Medical Council of India.

2. Total income from all sources combined did not have significant impact on the calorie intake in the regression exercise, therefore, not included in the model discussed in the paper.

3. In NSS there are primarily four categories of households in rural areas based on income criterion, 1) self-employed in agriculture 2) self-employed in non-agriculture 3) casual labour and 3) regular/salaried workers. 


\section{References}

1. Da Corta \& Venkateshwarlu, (1997), "Unfree Relations and the Feminisation of Agricultural Labour in Andhra Pradesh," in Byres, T.J., Karin Kapadia and Jens Lerche (1998): "Rural Labour Relations in India", India Research Press, New Delhi.

2. Jha, Praveen (1997), "Agricultural Labourer in India," Vikas Publishing House, Delhi.

3. Jha and Thakur (2016), "30 Years On: Work and Well Being in Rural Bihar," in Himanshu, Praveen Jha and Gerry Rodgers (Ed.) in 'The Changing Village in India: Insight from Longitudinal Research,' Oxford University Press, New Delhi.

4. Lerche, (1997), "Politics of the Poor: Agricultural Labourers and Political Transformations in Uttar Pradesh," in Byres, T.J., Karin Kapadia and Jens Lerche (1998), "Rural Labour Relations in India', India Research Press, New Delhi.

5. National Sample Survey Reports (Various Issues).

6. Ramchandran, V.K \&Vikas Rawal (2010), "The Impact of Liberalisation and Globalisation on India's Agrarian Economy," in Global Labour Journal, January.

7. Srivastava, Ravi (1998), "Rural Labour in Uttar Pradesh: Emerging Features of Subsistence, Contradiction and Resistance" in Byres, T.J., Karin Kapadia and Jens Lerche (1998), "Rural Labour Relations in India,' India Research Press, New Delhi.

8. Sundarayya (1976), “The Land Questions", All India Kisan Sabha. 